185, 116 (1960).

2) Randall, J. M., R. L. Bermann, V. Garrett and Waiss, JR. A. C.: Use of Bark to Remove Heavy Metal Ions from Waste Solutions. Forest Products J. 24 (9), 80 84 (1974).

3) Rogers, H. H. and D. E. Davis: Nutrient Removal by Waterhyacinth. Weed Science 20 (5), 423 428 (1972).


究 27 (4)，533〜 538 (1973).

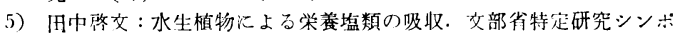
シウム, 肥料汇上る陸水の励濁と指標植物, 要爫集. 91 97 (1976).

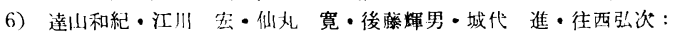

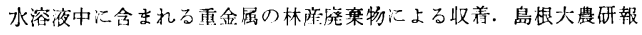
9, 58〜62 (1975).

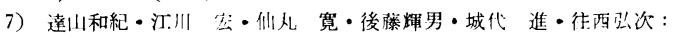

污摆水中に含まれる重金属の林颜廃裹物による除去。鳥根大農研報 9, $63 \sim 67$ (1975)

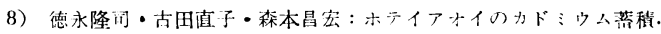
葦生化学 22 (4), 234 239 (1976).

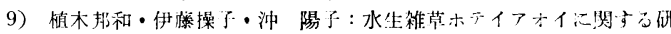

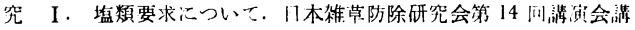
湍要告. 184 186 (1975).

10) Waiss, A. C., M. E. Wilfy, J. A. Kuhxile, A. L. Potter and R. M. MCCREADY: Absorption of Mercuric Cation by Tannins in Agricultural Residues. J. Env. Quality 2, 369 371 (1973).

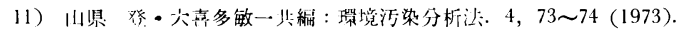

(1977 年. 6 月 6 日受付)

\title{
Sorption of Heavy Metals by the Water Hyacinth from the Metal Solutions
}

\author{
Kadzunori Tatsuyama, Hiroshi Egawa and Takefumi Yamagishi
}

Faculty of Agriculture, Shimane University, Matsue, Shimane

\section{Summary}

Removal of lead, cadmium and copper using water hyacinth (Eichhorina crassipes Solms) from the solution polluted by the metals were studied. Lead content of the plant roots increased as a result of culture on the solution containing $1 \mathrm{ppm}$ of the metal. The metal content of the root reached to the maximum a week after the begining of the cultivation, and then remained at the constant leavel. It seems that translation of the metal into the stem or leaves was less than the amount in the roots.

In other experiments, amount of the metals taken up by water hyacinth from the solutions containing $10 \mathrm{ppm}$ of lead, cadmium or copper, and from thier mixed solutions were determined. Lead was taken up in the highest amount, followed by copper and cadmium. Sorption of a metal was inhibited at the following conditions, namely, in the presence of other metals, at the strong acid side of the solution, and at low temperature of the solution.

\section{短 報}

\section{数種雑草種子の休眠覚醒の貯蔵条件による差異}

\author{
農林省農事試験場 片 岡 孝 義, 韓国農村振興庁作物試験場 金 昭 年 \\ Takayoshi KataOKA* and So Yeon KIM**: Effects of Storage \\ Conditions on Dormancy-awakening of Several Weed Seeds
}

種子の休眠覚醒過程が解明されている雑草は少なく， そのために, 雑草種子の自然条件下における生存状態を 解明する上でも, 試験に休眠覚醒種子を供試する上で
も，支障を来している。そこで，筆者らは，水田雑草を 中心に 7 種の雑草の休眠種子について, 貯蔵条件による 休眠覚醒の差異を調べた。

* Central Agricultural Experiment Station, Konosu, Saitama.

** Crop Experiment Station, Office of Rural Development, Suweon, Korea. 


\section{（1）実験の材料と方法}

1976 年秋に種子を採集し, 室内で風乾, 風選し，第 1 表のように温度と水分を異にした種々の条件で貯蔵し た。 $5^{\circ} \mathrm{C}, 30^{\circ} \mathrm{C}$ 貯蔵では合成樹脂製容器に, 戸外（第 1

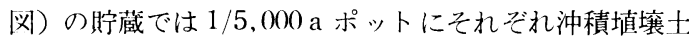

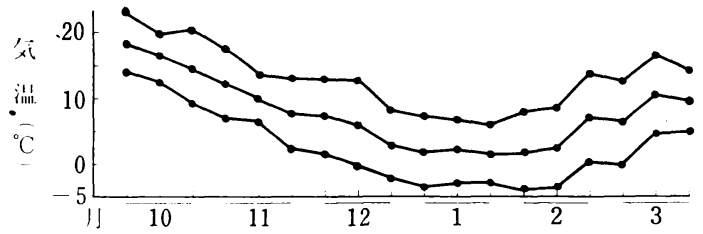

第 1 図 戸外の旬別最高・最低・平均気温

の鴻巣水田十袞をつめた。毎月 1 回，おおよそ50〜200 粒で発芽試験を行った。1反復。採種時期は，ヒメイス ビェ 8 月中旬，イヌビエ有芒種（別名ケイヌビエ） 9 月 上旬，タイヌビエ・オオイヌタデ 9 月中旬，コナギ・イ ヌホタルイ 9 月下旬，イボクサ 10 月中旬，また眝蔵条 件設定時期は野生ヒェ 3 種とオオイヌタデ 9 月下旬（た だし $5{ }^{\circ} \mathrm{C}$ 湛水土中区は 11 月中旬)，コナギ・イヌホタル イ 9 月下旬, イボクサ 10 月下旬であった。第 1 表で, 貯蔵条件は温度, 土䁃水分, 種子の位置の順に示した。 なお，畑 A と畑 B はいずれもポットの下部を土中に埋 めて降雨に遭わせて畑水分で経過させたが，畑 $\mathrm{A}$ の方 が土㙵水分がやや高かった。発芽試験は，コナギ・イヌ ホタルイの場合，湿潤ろ紙床では発芽しないため3)，井 水を満たして密栓したインキュベーションチューブを 用い, その他の雑草ではシャーレの湿潤ろ紙床を用い, 室内散光の入る $30^{\circ} \mathrm{C}$ の恒温器中で行った。

次に, 野生ヒエ 3 種について, $5{ }^{\circ} \mathrm{C}$ 畑土中区の種子を 発芽試験開始直前の 6 日間, $30^{\circ} \mathrm{C}$ の湛水土壤に埋没し,

1 月 20 日に発芽試験に供試した。

\section{（2）実験の結果と考察}

実験結果は第 1,2 表のとおりである。

タイヌビェ： $5^{\circ} \mathrm{C}$ の湛水土中区・畑土中区では 1 月 に発芽率が高まった。そして $5{ }^{\circ} \mathrm{C}$ 畑土中区では 1 月に は発芽率が $45 \%$ であったが， 6 日間の $30^{\circ} \mathrm{C}$ 湛水土中埋 没処理を加えた場合に発芽率が著しく高まり，休眠の程

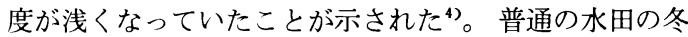
期の条件に近い戸外の畑水分の各区では $2 \sim 3$ 月ごろで も発芽率があまり高くなかったが，戸外畑 A 地表区で は 2 月に発芽率が高まった。本種では発芽率が一度高く なった後に低下寸る傾向がみられる区があったが，これ は二次休眠または死滅によるものと思われる ${ }^{4} 。 そ し て ，$ 宮原 ${ }^{4)}$ の報告を加えて検討すると，休眠覚醒種子を得る
第 1 表 種子貯蔵後の発芽率の推移

\begin{tabular}{|c|c|c|c|c|c|c|}
\hline \multirow[b]{2}{*}{ 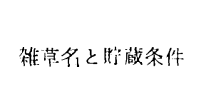 } & \multicolumn{6}{|c|}{ 発芽試験開始時期別の発芽溹 (約 2 週閒, \%) } \\
\hline & $\begin{array}{l}\text { 10月 } \\
21 \text { 日 }\end{array}$ & $\begin{array}{l}11 月 \\
19 \|\end{array}$ & $\begin{array}{l}\text { 12月 } \\
21 \prod\end{array}$ & $\begin{array}{c}1 \text { 月 } \\
24 \mathrm{~F}\end{array}$ & $\begin{array}{c}2 \text { 月 } \\
24 \text { 月 }\end{array}$ & $\begin{array}{c}3 \text { 月 } \\
25 П\end{array}$ \\
\hline \multicolumn{7}{|l|}{ タイヌビエ } \\
\hline $5{ }^{\circ} \mathrm{C}$ 湛 水 世中 & $\cdots$ & $\cdots$ & 16 & 71 & 35 & - \\
\hline $5^{\circ} \mathrm{C}$ 畑 上小 & 13 & 9 & 21 & 45 & 55 & - \\
\hline $30^{\circ} \mathrm{C}$ 踏水士: 中 & 7 & 0 & 24 & 17 & 58 & 42 \\
\hline 厅外渄水地表 & 11 & 4 & 4 & 5 & 45 & 25 \\
\hline 万外畑 $\mathrm{A}$ 土: 中 & 3 & 4 & 9 & 3 & 4 & 11 \\
\hline 户外畑 $\mathrm{A}$ 地表 & 0 & 18 & 5 & 14 & 68 & 27 \\
\hline 厂外畑 B 地表 & 0 & 21 & 0 & 0 & 12 & 27 \\
\hline \multicolumn{7}{|l|}{ イヌビエ有芒種 } \\
\hline $5{ }^{\circ} \mathrm{C}$ 茜 水土中 & - & - & 1 & 19 & 95 & - \\
\hline $5^{\circ} \mathrm{C}$ 畑土中 & 0 & 5 & 8 & 43 & 84 & - \\
\hline $30^{\circ} \mathrm{C}$ 湛 水土中 & 0 & 11 & 9 & 7 & 2 & 5 \\
\hline 戸外湛水地表 & 0 & 0 & 0 & 0 & 19 & 45 \\
\hline 万外畑 $\mathrm{A}$ 土中 & 0 & 0 & 0 & 6 & 0 & 32 \\
\hline 丁外畑 $\mathrm{A}$ 地甚 & 2 & 0 & 0 & 16 & 30 & 37 \\
\hline 召外畑 B 地表 & 2 & 2 & 5 & 0 & 2 & 90 \\
\hline \multicolumn{7}{|l|}{ ヒメイヌビエ } \\
\hline $5{ }^{\circ} \mathrm{C}$ 淇 水土中 & - & - & 5 & 0 & 12 & -- \\
\hline $5{ }^{\circ} \mathrm{C}$ 畑土 中 & 0 & 0 & 20 & 52 & 86 & - \\
\hline $30^{\circ} \mathrm{C}$ 湛 水土中 & 0 & 0 & 4 & 3 & 64 & 19 \\
\hline 户外湛水地表 & 0 & 2 & 8 & 5 & 4 & 50 \\
\hline 戸外畑 $\mathrm{A}$ 土中 & 23 & 1 & 12 & 13 & 72 & 45 \\
\hline 巨外畑 A 地表 & 0 & 0 & 15 & 6 & 14 & 50 \\
\hline 夏外畑 $\mathrm{B}$ 地表 & 0 & 0 & 0 & 0 & 90 & 59 \\
\hline \multicolumn{7}{|l|}{ コ ナ $キ$} \\
\hline $5{ }^{\circ} \mathrm{C}$ 湛 水土中 & 43 & 97 & 100 & 100 & 100 & - \\
\hline $5^{\circ} \mathrm{C}$ 畑 土中 & 71 & 97 & 93 & 100 & 99 & - \\
\hline $30^{\circ} \mathrm{C}$ 湛 水土中 & 51 & 73 & 41 & 90 & 92 & -- \\
\hline $30^{\circ} \mathrm{C}$ 畑 土中 & 28 & 85 & 66 & 100 & 97 & - \\
\hline 官外湛 水 地 表 & 10 & 68 & 一 & 99 & 99 & - \\
\hline 户外畑 $\mathrm{A}$ 土中 & 37 & 80 & 92 & 100 & 95 & - \\
\hline 戸外畑 $\mathrm{A}$ 地表 & 0 & 58 & 68 & 90 & 99 & - \\
\hline 室 内 風 㲦 & - & 16 & 19 & 95 & 98 & $\cdots$ \\
\hline \multicolumn{7}{|l|}{ イヌホタルイ } \\
\hline $5{ }^{\circ} \mathrm{C}$ 淽 水土中 & 4 & 13 & 27 & 23 & 57 & - \\
\hline $5{ }^{\circ} \mathrm{C}$ 畑土中 & 2 & 21 & 95 & 100 & 100 & - \\
\hline $30^{\circ} \mathrm{C}$ 湛 水土中 & 0 & 0 & 0 & 0 & 0 & 0 \\
\hline $30^{\circ} \mathrm{C}$ 畑 土 中 & 2 & 0 & 0 & 30 & 10 & 3 \\
\hline 戸外湛水地表 & 13 & 8 & 63 & 22 & 54 & 15 \\
\hline 戸外畑 $\mathrm{A}$ 土中 & 30 & 90 & 70 & 79 & 98 & 85 \\
\hline 户外烟 $\mathrm{A}$ 地表 & 9 & 0 & 23 & 7 & 72 & 44 \\
\hline 室内 風 乾 & 0 & 0 & 0 & 0 & 0 & 0 \\
\hline \multicolumn{7}{|l|}{ イポク サ } \\
\hline $5{ }^{\circ} \mathrm{C}$ 湛 水土中 & - & 0 & 4 & 67 & 10 & - \\
\hline $5^{\circ} \mathrm{C}$ 畑 中 & - & 6 & 5 & 92 & 36 & - \\
\hline $30^{\circ} \mathrm{C}$ 湛 水土中 & - & 0 & 0 & 1 & 0 & 0 \\
\hline $30^{\circ} \mathrm{C}$ 畑土 中 & - & 3 & 0 & 0 & 0 & 15 \\
\hline 戸外湛 水土中 & 一 & 0 & 8 & 89 & 50 & 63 \\
\hline 戸外湛 水地表 & - & 0 & 0 & 18 & 63 & 84 \\
\hline 戸外畑 $\mathrm{A}$ 土中 & - & 0 & 7 & 34 & 21 & 90 \\
\hline 室内 風 乾 & - & 0 & 0 & 0 & 0 & 0 \\
\hline \multicolumn{7}{|l|}{ オオイヌタデ } \\
\hline $5^{\circ} \mathrm{C}$ 畑土中 & 44 & 85 & 88 & 82 & 77 & - \\
\hline 戸外畑 B 地表 & 25 & - & 25 & 71 & 74 & - \\
\hline 室 内 風 & - & - & 25 & 一 & - & 一 \\
\hline
\end{tabular}

注）一注未調查 
第 2 表 $5{ }^{\circ} \mathrm{C}$ 畑水分土中貯蔵種子に対する $30^{\circ} \mathrm{C}$ 湛 水土中埋没処理の影響

\begin{tabular}{|c|c|c|c|c|}
\hline \multirow{2}{*}{ 雑 草 名 } & \multicolumn{2}{|c|}{$\begin{array}{l}\text { 無処理種子の発芽䒺 } \\
(1 \text { 月 } 24 \text { 日㯰床) }\end{array}$} & \multicolumn{2}{|c|}{$\begin{array}{c}6 \text { 日間処理後の発芽䒺 } \\
(1 \text { 月 } 20 \text { 日㯰床 })\end{array}$} \\
\hline & 7 日間 & 15 日 閒 & 5 月閪 & 18 日閒 \\
\hline タイヌビ エ & $44 \%$ & $45 \%$ & $92 \%$ & $92 \%$ \\
\hline イヌビェ有芒種 & 13 & 43 & 88 & 91 \\
\hline ヒメイヌビエ & 52 & 52 & 97 & 97 \\
\hline
\end{tabular}

ための貯蔵条件としては, $3 \sim 5{ }^{\circ} \mathrm{C}$ の湛水土中または畑 水分土中の貯蔵がよいと思われるが，低温湿潤条件で貯 蔵しておいた種子に $30^{\circ} \mathrm{C}$ 湛水土中埋没処理を加えて休 眠から覚醒させ，これを $3 \sim 5{ }^{\circ} \mathrm{C} て ゙$ 眝蔵しておくことに よって, 高い発芽率が早期から長期間にわたって得られ る。

イヌビエ有芒種：結果はタイヌビエの場合と大差なか ったが，発芽率が高まる時期がやや遅かった点，3月ま でには一度上昇した発芽率の低下が認められなかった点 が，タイヌビエの場合と異なった。高橋5) も，本種に明 確な二次休眠を認めていない。なお，同氏の $5{ }^{\circ} \mathrm{C}$ 畑水分 貯蔵の場合, 発芽に変温が必要で, 浅い休眠状態で推移 した。本実験の結果に高橋5) の結果を加えて検討する と, 休眠覚醒種子を得るための貯蔵条件としては, 夕イ ヌビエの場合とほぼ同様でよいと思われ， $30^{\circ} \mathrm{C}$ 湛水土 中埋没処理を加えることも有効であろう。

ヒメイヌビエ： $5{ }^{\circ} \mathrm{C}$ 畑土中区では，1月より発芽率が 高まり, またこの時期には $30^{\circ} \mathrm{C}$ 湛水土中埋没処理の休 眠覚醒効果も認められた。戸外の各区は $2 \sim 3$ 月に発芽 率が高まったが， 2 月に比べて 3 月の発芽率が低い区も みられた。渡辺らは, $5{ }^{\circ} \mathrm{C}$ 地中貯蔵の場合, 完全には休 眠から覚めず, 暗床では発芽に変温条件が必要であっ $た^{7)}$ とし，また，春期の地温上昇時に地中で死滅する現 象を認めている ${ }^{8)}$ 。休眠覚醒種子を得るための貯蔵条件 としては, $3 \sim 5^{\circ} \mathrm{C}$ の畑水分土中の貯蔵がよいと思わ れ, タイヌビエの場合と同様に $30^{\circ} \mathrm{C}$ 湛水土中埋没処理 を加えることも有効であろら。

コナギ：休眠性が浅く, 室内風乾貯藏でも 1 月には 発芽率が高まったが， $5{ }^{\circ} \mathrm{C}$ の湛水土中区・畑土中区で休
眠覚醒の進行がもっとも速やかであり，また 2 月までに は二次休眠の現象は認められなかった。休眠覚醒種子を 得るための貯蔵条件としては, $5{ }^{\circ} \mathrm{C}$ の湛水土中または畑 水分土中の貯蔵がよく, この条件で恒温暗条件で発芽す る種子が得られる1”。

イヌホタルイ：局外畑土中区・ $5{ }^{\circ} \mathrm{C}$ 烟土中区で休眠 覚醒が速やかで， $5{ }^{\circ} \mathrm{C}$ 湛水土中区では休眠覚醒が遅れ， $30^{\circ} \mathrm{C}$ 湛水土中区・室内風乾区では 3 月まで発芽率が高 まらなかった。一部の区では 3 月に発芽率が低下寸る傾 向がみられた。休眠覚醒種子を得るための貯蔵条件とし ては, $5{ }^{\circ} \mathrm{C}$ 畑水分土中の貯蔵がよい。

なお，ホタルイを $5{ }^{\circ} \mathrm{C}$ 烟水分土中に貯蔵して調べた 結果では， $2 \sim 3$ 月でも発芽率は $20 \%$ 程度で，この貯 蔵条件は休眠覚醒にあまり有効ではなく, イヌホタルイ とは休眠性が異なるようである。

イボクサ：休眠性が深いが， $5{ }^{\circ} \mathrm{C}$ の畑土中区・湛水土 中区や戸外湛水土中区では 1 月に発芽率が高まった。し かし，これらの区ではその後発芽率が低下寸る現象がみ られた。休眠覚醒璉子を得るための貯蔵条件としては, $5{ }^{\circ} \mathrm{C}$ の畑水分土中または湛水土中の貯蔵がよい上うで あるが，長期間貯蔵の場合に発芽率が低下寸る可能性が ある。

オオイヌタデ：室内風乾区では 11 月には発芽率が低 かったが， $5{ }^{\circ} \mathrm{C}$ 畑土中区では 11 月には発芽率が高く, 2 月まで発芽率が低下しなかった。岩田ら ${ }^{2)}$, 渡辺ら ${ }^{6,7)}$ も, 本種の休眠覚醒に低温湿潤条件が有効であるとして いる。休眠覚醒種子を得るための貯蔵条件としては， 5 ${ }^{\circ} \mathrm{C}$ の畑水分土中の貯蔵がよい。

\section{引用 文 献}

1) 一坂英雄 - 片岡孝義 : 雑草研究 22 (別号), 94 96 (1977).

2）岩田岩保・高柳 繁: 雑草研究 17, 33 38 (1974).

3）片岡孝義・金昭年: 雑草研究 22 (別号), 100 102 (1977).

4）宮原益次：農事試研報（16）, 1 62 (1972).

5）高橋 均：農事試研報 (21)，161 210 (1974).

6) 渡辺 泰・広川交彦: 雑草研究 9, 36 41 (1969).

7) 渡辺 泰・広川交彦: 雑草研究 17, 24 28 (1974).

8) 渡边 泰・広川交彦: 雑草研究 17, 29 33 (1974).

(1977 年 6 月 13 日受付) 